\title{
Production of extracellular fatty acid using engineered Escherichia coli
}

\author{
Hui Liư ${ }^{\dagger}$ Chao Yư, Dexin Feng, Tao Cheng, Xin Meng, Wei Liu, Huibin Zou and Mo Xian*
}

\begin{abstract}
Background: As an alternative for economic biodiesel production, the microbial production of extracellular fatty acid from renewable resources is receiving more concerns recently, since the separation of fatty acid from microorganism cells is normally involved in a series of energy-intensive steps. Many attempts have been made to construct fatty acid producing strains by targeting genes in the fatty acid biosynthetic pathway, while few studies focused on the cultivation process and the mass transfer kinetics.

Results: In this study, both strain improvements and cultivation process strategies were applied to increase extracellular fatty acid production by engineered Escherichia coli. Our results showed overexpressing TesA and the deletion of fadL in E. coli BL21 (DE3) improved extracellular fatty acid production, while deletion of fadD didn't strengthen the extracellular fatty acid production for an undetermined mechanism. Moreover, the cultivation process controls contributed greatly to extracellular fatty acid production with respect to titer, cell growth and productivity by adjusting the temperature, adding ampicillin and employing on-line extraction. Under optimal conditions, the E. coli strain (pACY-'tesA- $\Delta$ fadL) produced $4.8 \mathrm{~g} \mathrm{~L}^{-1}$ extracellular fatty acid, with the specific productivity of $0.02 \mathrm{~g} \mathrm{~h}^{-1} \mathrm{~g}^{-1}$ dry cell mass, and the yield of $4.4 \%$ on glucose, while the ratios of cell-associated fatty acid versus extracellular fatty acid were kept below 0.5 after $15 \mathrm{~h}$ of cultivation. The fatty acids included C12:1, C12:0, C14:1, C14:0, C16:1, C16:0, C18:1, C18:0. The composition was dominated by C14 and C16 saturated and unsaturated fatty acids. Using the strain PACY-'tesA, similar results appeared under the same culture conditions and the titer was also much higher than that ever reported previously, which suggested that the supposedly superior strain did not necessarily perform best for the efficient production of desired product. The strain PACY-tesA could also be chosen as the original strain for the next genetic manipulations.
\end{abstract}

Conclusions: The general strategy of metabolic engineering for the extracellular fatty acid production should be the cyclic optimization between cultivation performance and strain improvements. On the basis of our cultivation process optimization, strain improvements should be further carried out for the effective and cost-effective production process.

Keywords: Extracellular fatty acid, Extraction, Cultivation, Escherichia coli, Strain improvement

\section{Background}

Clean and renewable transportation fuels such as microbial biodiesel are greatly pushed forward in order to cope with global warming and energy shortage. Microbial fatty acid might become one of the potential feedstock for biodiesel production in the future since it has the following advantages: renewability, short production cycle, less labor requirement, less affection by venue, season and climate,

\footnotetext{
* Correspondence: xianmo@gibebt.ac.cn

${ }^{\dagger}$ Equal contributors

Key Laboratory of Biofuel, Qingdao Institute of Bioenergy and Bioprocess

Technology, Chinese Academy of Sciences, Qingdao 266101, China
}

and easier to scale up [1,2]. Prior to the conversion to biodiesel via esterification, microbial fatty acids have to be separated from cells through a series of energy-intensive steps such as cell harvest, drying and solvent extraction [3]. Among the energy-intensive processes, the cost of cell harvest usually accounts for $70-80 \%$ of total cost of biofuel production $[4,5]$. In order to skip these separation processes, the microbial production of extracellular fatty acid is receiving more concerns recently [3].

Although the mechanism of fatty acid secretion has not been illustrated definitely yet, it was reported that the fatty acid export out of cells could be through 
diffusion by concentration driven or through transportation by carrier proteins such as FadL, MsbA and so on [6-8]. Therefore, the process optimization could be employed to improve extracellular fatty acid production by increasing the driving force of fatty acid diffusion across the membrane. Furthermore, we could also enhance the extracellular fatty acid production in engineered $E$. coli by expressing the thioesterase or deleting the Fad gene family. There is now ample evidence that fatty acid export out of cells is relevant with the thioesterase gene and Fad gene family. The expression of full-length acyl-ACP thioesterase cDNA from Umbellularia californica in the E. coli fatty acid-degradation mutant strain $\left(f a d D^{-}\right)$resulted in the secretion of free fatty acid into medium [9]. The mutant of Saccharomyces cerevisiae deficient in acyl-CoA synthetases could secrete fatty acid out of cells with a maximum titer of $200 \mu \mathrm{mol} \mathrm{L}{ }^{-1}$ [10]. An E. coli fatty acid producing strain could produce $2.5 \mathrm{gL}^{-1}$ of total fatty acid with $<10 \%$ of the fatty acid pool secreted into the supernatant medium, which was constructed with four genotypic changes (deletion of the fadD gene, overexpression of endogenous ACC and 'TesA as well as heterologous plant thioesterase) [11]. To avoid costly biomass recovery, the cyanobacteria was modified for fatty acid production by adding thioesterase genes and weakening polar cell wall layers and the extracellular fatty acid titer was $197 \mathrm{mg} \mathrm{L}^{-1}$ [5].

Besides the traditional oleaginous microorganisms like microalgae, fungi and yeast, the industrial strain E. coli is becoming a new focus for fatty acid production and some breakthroughs have been made recently [12]. The formation of malonyl- CoA from acetyl- CoA catalyzed by acetyl- CoA carboxylase (ACC) is the first key ratelimiting step of fatty acid biosynthetic pathway $[13,14]$. The overexpression of ACC in E. coli has led to an increase in the rate of fatty acid synthesis [13]. Expression of bacterial or plant acyl-ACP thioesterases can reduce the cellular acyl-ACP concentration, decrease the feedback inhibition of fatty acyl-ACP and increase fatty acid production in E. coli $[9,13,15,16]$. A 7 -fold increase of total fatty acid production was observed by eliminating $\beta$-oxidation in E. coli, overexpressing ACC and expressing plant acyl-ACP thioesterases from $U$. californica in low copy number plasmids, and the fatty acid was successfully converted to alkane by a catalytic reaction. In the $f a d D$ deleted strain, coexpression of three genes, thioesterases from Cinnamomum camphorum and $E$. coli, as well as ACC from E. coli resulted in 20-fold enhancement of total fatty acid production in shake flasks. $2.5 \mathrm{gL}^{-1}$ fatty acids were produced by this engineered strain in fed-batch cultivation, but no cultivation optimization was further conducted [11]. Although many efforts have been done to increase fatty acid production by targeting the genes in the fatty acid biosynthetic pathway, the productivity $\left(4.5 \mathrm{~g} \mathrm{~L}^{-1} \mathrm{~d}^{-1}\right)$ is still not satisfied for the scale-up application [17].

Generally speaking, the construction of genetically engineered strains for fatty acid production only focused on the terminal pathway, such as the overexpression of the rate-limiting enzyme and removing feedback inhibitions in the fatty acid biosynthetic pathway. However, these approaches did not always result in great increment because the kinetic fermentative behavior of strains and the integrated function of the whole metabolic network were neglected [18-20]. The general strategy of metabolic engineering for the extracellular fatty acid production should be the cyclic optimization between cultivation performance and strain improvements [19]. Using developed strains, cultivation process should be performed. On the basis of cultivation performance, further metabolic engineering should be carried out for the strain improvement. The supposedly superior strain did not necessarily perform best for the efficient production of fatty acid [19]. Actually lots of factors could influence fatty acid production in the cultivation process such as cultivation temperature, which could affect the expression of genes, product transport out of cells, cell growth and productivity and so on [21-25]. Therefore, the bioprocess optimization for fatty acid production should be further considered.

In the present paper, to improve the production of extracellular fatty acid in metabolically engineered $E$. coli, a strain was first constructed by cytosolic overexpression of $E$. coli thioesterase. Then two derivative strains which contained the deletions of fadD and $f a d L$ respectively were constructed to inhibit the $\beta$-oxidation pathway or re-absorbance of extracellular fatty acid. Furthermore, considering the mass transfer kinetics during fatty acid diffusion out of cells, several cultivation strategies were employed to enhance extracellular fatty acid production, which included a two-stage control of cultivation temperature, an on-line integration of fatty acid separation with cultivation process, as well as ampicillin supplementation.

\section{Results and discussion}

Extracellular fatty acid production by $E$. coli pACY-'tes $A$

\section{overexpressing native thioesterase}

It was reported that the periplasmic expression of TesA (native E. coli thioesterase) in E. coli led to limited fatty acid accumulation and the cytosolic expression of 'TesA (a 'leadless' version of TesA without the $\mathrm{NH}_{2}$-terminal 26 amino acid residues) could greatly contribute to the production and secretion of free fatty acids in cells $[11,12,15,16,26]$. Therefore, both tes $A$ and 'tes $A$ were cloned and transformed respectively into the strain BL21 (DE3) to promote the production of fatty acid. The overexpression of 'TesA resulted in increment of both cell- 
associated fatty acid and extracellular fatty acid production in shake flasks (Table 1), which was similar to previous findings [12].

Although the shake flasks are of outstanding importance for the practical application in screening projects, some disadvantages such as oxygen limitation, are also associated with shake bioreactors [27]. So the producer expressing 'TesA was further investigated under fed-batch cultivation conditions in 5-L jar fermentors. As shown in Figure 1A, the extracellular fatty acid production reached $2.0 \mathrm{~g} \mathrm{~L}^{-1}$ with a specific productivity of $0.008 \mathrm{~g} \mathrm{~h}^{-1} \mathrm{~g}^{-1}$ dry cell and a yield of $1.9 \%(\mathrm{w} / \mathrm{w})$ on glucose during the first $32 \mathrm{~h}$ of cultivation. The ratios of cell-associated fatty acid versus extracellular fatty acid varied between 2.3 and 3.4 from 8 to $64 \mathrm{~h}$, which indicated that the cell-associated fatty acid concentrations were always much higher than the extracellular ones during the cultivation process.

Due to the extracellular fatty acid titers ever reported were much lower than $1 \mathrm{gL}^{-1}$, the results above indicated that cytosolic E. coli thioesterase was one key enzyme for extracellular fatty acid production. Although 'TesA was regarded as an essential enzyme for fatty acid production and secretion in E. coli, no one ever specified the performance of fatty acid producer expressing 'TesA before, using ratio of cell-associated fatty acid versus extracellular fatty acid as a parameter.

\section{Extracellular fatty acid production using different strategies of cultivation temperature control}

After $8 \mathrm{~h}$ of cultivation in a 5 - $\mathrm{L}$ jar fermentor at $37^{\circ} \mathrm{C}$, the $E$. coli strain pACY-'tesA was induced with IPTG in 3 different control modes as follows: $\mathrm{M} 1,37^{\circ} \mathrm{C}$ for the whole process; $\mathrm{M} 2,30^{\circ} \mathrm{C}$ from $8 \mathrm{~h}$ to $72 \mathrm{~h}$; standard cultivation conditions, $34^{\circ} \mathrm{C}$ from $8 \mathrm{~h}$ to $26 \mathrm{~h}$, and then shifted to $30^{\circ} \mathrm{C}$ from $26 \mathrm{~h}$ to $72 \mathrm{~h}$.

As shown in Figure 2, during the first $32 \mathrm{~h}$ of cultivation, the extracellular fatty acid production increased fast and the specific productivity reached $0.003 \mathrm{gh}^{-1} \mathrm{~g}^{-1}$ dry cell (M1), $0.001 \mathrm{gh}^{-1} \mathrm{~g}^{-1}$ dry cell (M2), $0.008 \mathrm{~g} \mathrm{~h}^{-1} \mathrm{~g}^{-1}$ dry cell (standard cultivation conditions). The yield reached $0.66 \%$ (M1), $0.41 \%(\mathrm{M} 2)$ and $1.9 \%$ (standard cultivation conditions). The maximal extracellular fatty acid production reached $0.6 \mathrm{~g} \mathrm{~L}^{-1}(\mathrm{M} 1), 0.4 \mathrm{~g} \mathrm{~L}^{-1}(\mathrm{M} 2)$ and $2.0 \mathrm{~g} \mathrm{~L}^{-1}$ (standard cultivation conditions) after $24 \mathrm{~h}$ of induction. The corresponding volumetric productivities were $0.5 \mathrm{gL}^{-1} \mathrm{~d}^{-1}$
(M1), $0.2 \mathrm{~g} \mathrm{~L}^{-1} \mathrm{~d}^{-1}$ (M2) and $1.9 \mathrm{~g} \mathrm{~L}^{-1} \mathrm{~d}^{-1}$ (standard cultivation conditions), respectively. The two-stage mode (standard cultivation conditions) contributed greatly to fatty acid production with respect to fatty acid titer, cell growth and fatty acid productivity. We also showed the impact of cultivation temperature on the ratio of cellassociated fatty acid versus extracellular fatty acid in Figure 2B. Contrasted to M1 and M2, the extracellular fatty acid was greatly accumulated under standard cultivation conditions with a high titer of $2.0 \mathrm{~g} \mathrm{~L}^{-1}$ at $32 \mathrm{~h}$ and the ratios of cell-associated fatty acid versus extracellular fatty acid varied between 2.3 and 3.4 from 8 to $64 \mathrm{~h}$.

Low induction temperatures $30^{\circ} \mathrm{C}$ or $25^{\circ} \mathrm{C}$ can increase the activity of recombinant enzymes at the expenses of the final yield and lower the inclusion bodies in genetically engineered E. coli $[22,23,28]$. Based on this consideration, previously fatty acid production by expressing thioesterase in $E$. coli has been conducted at low temperatures $30^{\circ} \mathrm{C}$ or $25^{\circ} \mathrm{C}[11,12,17,21]$. However, a successful control of cultivation temperature has to balance the enzyme expression, cell growth and product formation, etc [22]. In this study, the higher induction temperatures $\left(37^{\circ} \mathrm{C}, 34^{\circ} \mathrm{C}\right)$ in $\mathrm{M} 1$ and the two-stage mode could greatly contribute to the increments of extracellular fatty acid production and cell growth compared with $30^{\circ} \mathrm{C}$ in $\mathrm{M} 2$ in the first $26 \mathrm{~h}$ of cultivation (Figure 2). However, after $26 \mathrm{~h}$ the induction temperature $30^{\circ} \mathrm{C}$ in $\mathrm{M} 2$ and the two-stage mode increased the rates of extracellular fatty acids production and cell growth.

\section{Extracellular fatty acid production by E. coli $\mathrm{pACY}$-'tes $A$ $-\Delta f a d D$}

As shown in Figure 2A, the extracellular fatty acid production by E. coli pACY-'tesA decreased after 56 h. Due to the extracellular fatty acid in the cultivation broth might be reabsorbed and consumed by the cells through $\beta$-oxidation pathway, we tried to address the problem with deletion of $f a d D$ in $E$. coli to stop the $\beta$-oxidation. The extracellular fatty acid production reached $1.2 \mathrm{~g} \mathrm{~L}^{-1}$, with the specific productivity of $0.003 \mathrm{~g} \mathrm{~h}^{-1} \mathrm{~g}^{-1}$ dry cell, the volumetric productivity of $1.1 \mathrm{~g} \mathrm{~L}^{-1} \mathrm{~d}^{-1}$ and the yield of $1.8 \%$ after $32 \mathrm{~h}$ of cultivation (Figure 1). In this case, the extracellular fatty acid produced by strain pACYtes $A-\Delta f a d D$ was lower than that of the original strain

Table 1 Extracellular fatty acid production by gene engineered $E$. coli under shake flask conditions

\begin{tabular}{llll}
\hline Strains & OD $_{\mathbf{6 0 0}}$ & Extracellular fatty acid production $\left(\mathbf{m g ~ L}^{\mathbf{- 1}}\right)$ & Cell-associated fatty acid production $\left(\mathbf{m g ~ L}^{\mathbf{- 1}}\right)$ \\
\hline BL21 (DE3) & $2.64 \pm 0.32$ & $5.5 \pm 1.1$ & $129.4 \pm 3.0$ \\
BL21 (DE3) /pACYCDuet-1 & $2.81 \pm 0.21$ & $7.5 \pm 2.1$ & $117.6 \pm 3.1$ \\
BL21 (DE3) /pACY-tesA & $3.31 \pm 0.26$ & $25.2 \pm 9.1$ & $182.8 \pm 6.9$ \\
BL21 (DE3) /pACY-'tesA & $3.48 \pm 0.31$ & $40 \pm 5$ & $539 \pm 11$ \\
\hline
\end{tabular}




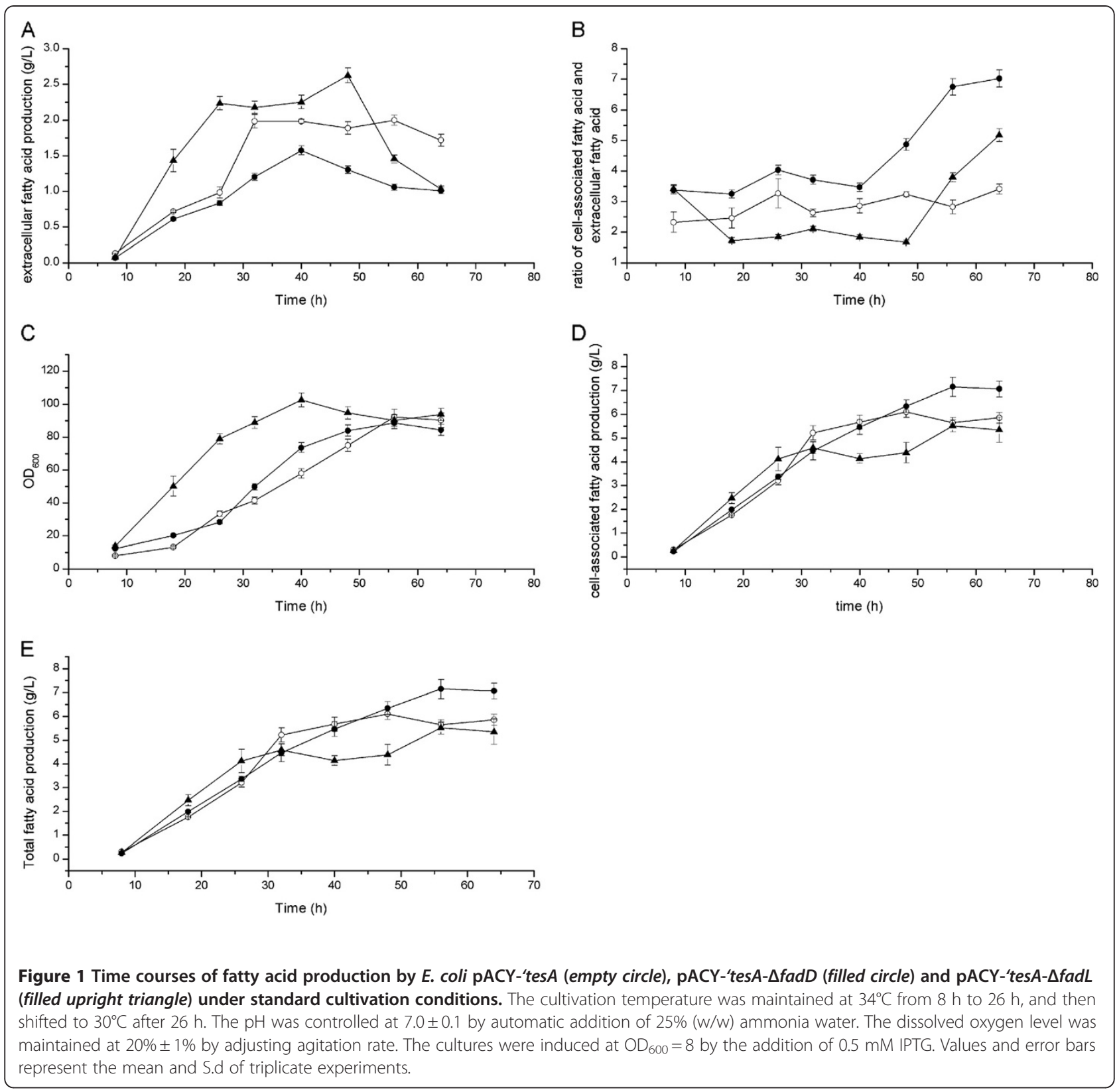

under cultivation conditions with respect to titer, specific productivity and yield. However, similar to other previous reports $[9,11,12]$, we found the increase of total fatty acid production in $E$. coli with the deletion of $f a d D$.

FadD (acyl-CoA synthetase) is the first enzyme in fatty acid $\beta$-oxidation pathway, and knockout of this enzyme could contribute to fatty acid accumulation. FadD can increase the concentration gradient between extracellular and intracellular fatty acid by converting fatty acid into acyl-CoA and contribute to the uptake of fatty acid [6]. In contrast, the deletion of $f a d D$ might increase the concentration of free fatty acid in the cytosol and enhance the export of fatty acid out of cells. However, our results suggested that the deletion of $f a d D$ could not improve the extracellular fatty acid production when the cellassociated fatty acid titer was high. Therefore, the extracellular fatty acid production was not only determined by the concentration gradient, but also related with other carrier proteins or some undetermined mechanisms such as the state of cells $[9,10,26]$. The reduced or flattened extracellular fatty acid production in Figures 1 and 2 could all be due to the state of cells, and the same trend was ever reported in S. cerevisiae previously [10].

Only in the E. coli fatty acid-degradation mutant strain K27 $\left(f a d D^{-}\right)$, the expression of full-length acyl-ACP thioesterase cDNA from $U$. californica could result in 

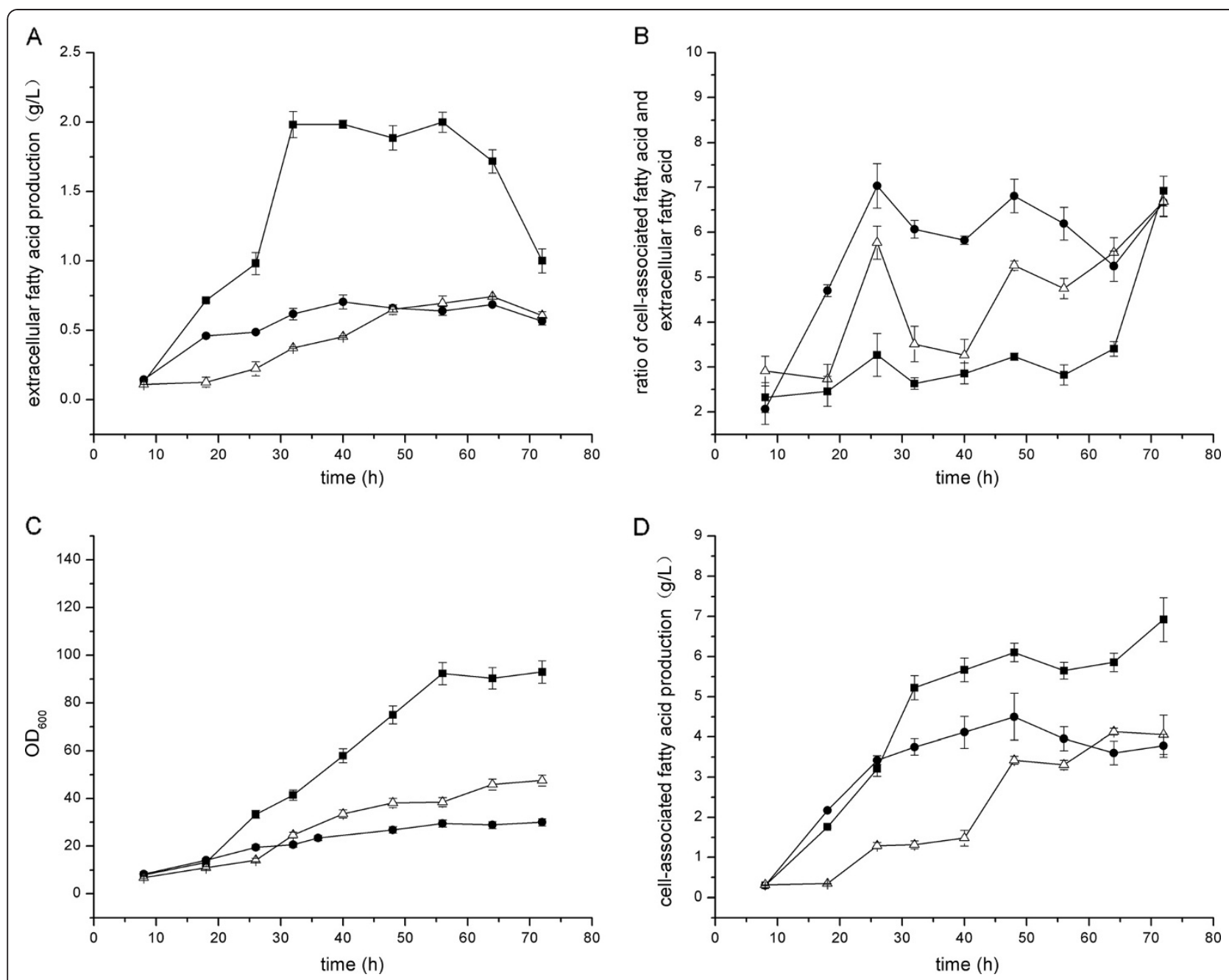

Figure 2 Time courses of fatty acid production by E. coli pACY-'tes A at different induction temperatures. After $8 \mathrm{~h}$ of the initial cultivation at $37^{\circ} \mathrm{C}$, the fatty acid producing strain PACY-'tes A was induced with IPTG in 3 temperature control modes as follows: M1 (filled circle), $37^{\circ} \mathrm{C}$ for the whole process; $\mathrm{M} 2$ (empty upright triangle), $30^{\circ} \mathrm{C}$ from $8 \mathrm{~h}$ to $72 \mathrm{~h}$; standard cultivation conditions (filled square), $34^{\circ} \mathrm{C}$ from $8 \mathrm{~h}$ to $26 \mathrm{~h}$, and then shifted to $30^{\circ} \mathrm{C}$ from $26 \mathrm{~h}$ to $72 \mathrm{~h}$. The pH was controlled at $7.0 \pm 0.1$ by automatic addition of $25 \%(\mathrm{w} / \mathrm{w})$ ammonia water. The dissolved oxygen level was maintained at $20 \% \pm 1 \%$ by adjusting agitation rate. Values and error bars represent the mean and S.d of triplicate experiments.

the secretion of free fatty acid into medium [9]. The disparate results with respect to the effects of FadD on extracellular fatty acid production might be due to the different hosts and thioesterases.

\section{Extracellular fatty acid production by $E$. coli pACY-'tes A $-\Delta f a d L$}

We also tested the deletion of the outer membrane protein FadL of E. coli, and an obvious increase of extracellular fatty acid was observed under fed-batch cultivation conditions. After $32 \mathrm{~h}$ of cultivation, the extracellular fatty acid production reached $2.2 \mathrm{~g} \mathrm{~L}^{-1}$, with the specific productivity of $0.004 \mathrm{~g} \mathrm{~h}^{-1} \mathrm{~g}^{-1}$ dry cell, the volumetric productivity of $2.1 \mathrm{~g} \mathrm{~L}^{-1} \mathrm{~d}^{-1}$ and the yield of $2.6 \%$ (Figure 1).
The outer membrane protein FadL of E. coli is a fatty acid transporter membrane protein, which is responsible for the import of long chain fatty acid across the cytoplasmic membrane into cells [29]. Our results suggested that the deletion of $f a d L$ gene could greatly contribute to the extracellular fatty acid production.

\section{Extracellular fatty acid production using on-line integration of separation with cultivation}

We also attempted to use on-line extraction during cultivation process as it was successfully applied in the production of organic acids and amino acids [30,31]. Considering the low water solubility, no tendency for emulsification, sufficient biocompatibility (Table 2), and high solubility of fatty 
Table 2 The inhibition of tributyl phosphate (TBP) on E.coli growth

\begin{tabular}{llllllllll}
\hline TBP concentration $\left(\mathbf{g ~ L}^{-\mathbf{1}}\right)$ & $\mathbf{0}$ & $\mathbf{0 . 5}$ & $\mathbf{1}$ & $\mathbf{2}$ & $\mathbf{4}$ & $\mathbf{8}$ & $\mathbf{1 6}$ & $\mathbf{3 2}$ & $\mathbf{6 4}$ \\
\hline $\mathrm{OD}_{600}$ & $2.11 \pm 0.11$ & $1.95 \pm 0.23$ & $1.89 \pm 0.21$ & $2.15 \pm 0.24$ & $2.05 \pm 0.23$ & $1.98 \pm 0.12$ & $1.76 \pm 0.31$ & $1.47 \pm 0.15$ & $1.15 \pm 0.17$ \\
\hline $\mathrm{A}$
\end{tabular}

A single colony of $E$. coli pACY-'tes $A$ was inoculated to $3 \mathrm{~mL} \mathrm{M9} \mathrm{minimal} \mathrm{medium} \mathrm{supplemented} \mathrm{with} \mathrm{glucose}\left(20 \mathrm{~g} \mathrm{~L}^{-1}\right)$ as primary carbon source and $34 \mu \mathrm{g} \mathrm{mL}{ }^{-1}$ chloramphenicol and cultured at $37^{\circ} \mathrm{C}$ for $12 \mathrm{~h}$. One percent $(\mathrm{v} / \mathrm{v})$ inocula was added aseptically to $3 \mathrm{~mL} \mathrm{M9} \mathrm{minimal} \mathrm{medium} \mathrm{supplemented} \mathrm{with} \mathrm{glucose} \mathrm{(} 20 \mathrm{gL} \mathrm{L}^{-1}$ ) as primary carbon source, various concentrations of TBP and $34 \mu \mathrm{g} \mathrm{mL}^{-1}$ chloramphenicol, and was cultivated at $37^{\circ} \mathrm{C}$ and $180 \mathrm{rpm}$ for $12 \mathrm{~h}$. Values and error bars represent the mean and S.d of triplicate experiments.

acids (Table 3), tributyl phosphate (TBP) was chosen to be the solvent for the on-line extraction.

The standard cultivation conditions and the on-line integration of separation with cultivation process were employed. As shown in Figure 3, the integrated extraction increased the extracellular fatty acid production to $2.5 \mathrm{~g} \mathrm{~L}^{-1}$ at $79 \mathrm{~h}$, with the volumetric productivity of $0.85 \mathrm{~g} \mathrm{~L}^{-1} \mathrm{~d}^{-1}$, the specific productivity of $0.001 \mathrm{gh}^{-1} \mathrm{~g}^{-1}$ dry cell mass, and the yield of $0.96 \%$ on glucose. The extracellular fatty acid production kept increasing even after $40 \mathrm{~h}$ of cultivation, and the ratios of cell-associated fatty acid versus extracellular fatty acid were reduced to 2.3 at $79 \mathrm{~h}$.

The on-line integration of separation with cultivation process was more effective than the unintegrated process for the extracellular fatty acid production. The decline in extracellular fatty acid production seemed inevitable after $56 \mathrm{~h}$ in the unintegrated cultivation processes (Figure 3). In contrast, the on-line extraction could increase the extracellular fatty acid production 2.8 times at $79 \mathrm{~h}$. Although the contribution of on-line extraction to the total fatty acid was limited, the on-line integration of separation with cultivation process could still be a potential economical route for extracellular fatty acid production, because the in situ product removal (ISPR) could increase the product yield, reduce process time and cut down running costs and capital expenditure [32].

Lennen et al. used alkane as an extractant that was directly mixed with cultivation broth for extracellular fatty acid production in E. coli. The resulting emulsions were involved in a series of separation processes. Moreover, the experiments were performed at shake-flask level, and the extracellular fatty acid production was not clearly indicated [21]. In our case, the extractant TBP and the external cycle system were employed for the online extraction, which avoided the emulsification and the separation of emulsion.

The on-line extraction was necessary for the extracellular fatty acid production especially in the case of high fatty acid titer in the medium. Due to fatty acids accumulation

Table 3 The solubility of fatty acid in tributyl phosphate (TBP)

\begin{tabular}{lllll}
\hline Fatty acid & C12:0 & C14:0 & C16:0 & C18:0 \\
\hline Solubility $(\mathrm{g} / \mathrm{L})$ & $666.7 \pm 0.1$ & $444.4 \pm 0.1$ & $277.80 \pm 0.06$ & $100.00 \pm 0.05$
\end{tabular}

The solubility of fatty acid in TBP was determined by gravimetric method at $20^{\circ} \mathrm{C}$. Values and error bars represent the mean and S.d of triplicate experiments. in the cultivation broth, a lot of foam formed in the middle and late periods of cultivation and the huge fluctuation of dissolved oxygen concentration happened, which caused antifoam consumed too much and had negative effects on cultivation process control. The on-line extraction could increase the stability of cultivation process control through reducing the fatty acid titer in medium.

\section{Extracellular fatty acid production by ampicillin supplementation in medium}

Ampicillin dose over $5 \mathrm{U} \mathrm{mL}^{-1}$ in shake flasks resulted in some inhibition on cell growth, while the ratios of cell-associated fatty acid versus extracellular fatty acid were reduced. So we investigated the effects of ampicillin supplementation with $5 \mathrm{U} \mathrm{mL}^{-1}$ as an example on the extracellular fatty acid production using E. coli pACY-'tesA under fed-batch cultivation conditions. The standard cultivation conditions and the on-line integration of separation with cultivation process were employed in this case. As shown in Figure 4, the extracellular fatty acid production reached $5.1 \mathrm{~g} \mathrm{~L}^{-1}$ at $38 \mathrm{~h}$ with the volumetric productivity of $4.3 \mathrm{~g} \mathrm{~L}^{-1} \mathrm{~d}^{-1}$, the specific productivity of $0.02 \mathrm{~g} \mathrm{~h}^{-1} \mathrm{~g}^{-1} \mathrm{dry}$ cell mass, the yield of $4.1 \%$ on glucose. The ratios of cellassociated fatty acid versus extracellular fatty acid were kept below 0.7 after $15 \mathrm{~h}$ of cultivation. Obviously the addition of ampicillin in the cultivation broth enhanced the fatty acid secretion.

Cell envelopes were the barrier to fatty acid export out of cells. Ampicillin supplementation could positively affect the extracellular fatty acid production by alleviating this barrier in our case. A successful example was given previously in glutamate production by Corynebacterium glutamicum. In their case, ampicillin destroyed the integrity of cell walls by its addition in cultivation broth, enhanced the glutamate export out of cells and contributed to the overproduction of glutamate successfully [33].

Due to ampicillin cost and waste water treatment, the cost could be high for fatty acid production with the ampicillin addition in the cultivation process, which was not feasible for biofuel application. In order to reduce the cost and avoid using ampicillin, the deletion of the peptidoglycan assembly protein (PBP2) in E. coli pACY-'tesA could be employed. Through binding the PBP2 in E. coli, ampicillin can inhibit the wall peptidoglycan assembly and weaken the polar cell wall layers $[34,35]$. So, the direct deletion of PBP2 in E. coli could also weaken the wall peptidoglycan layers and 


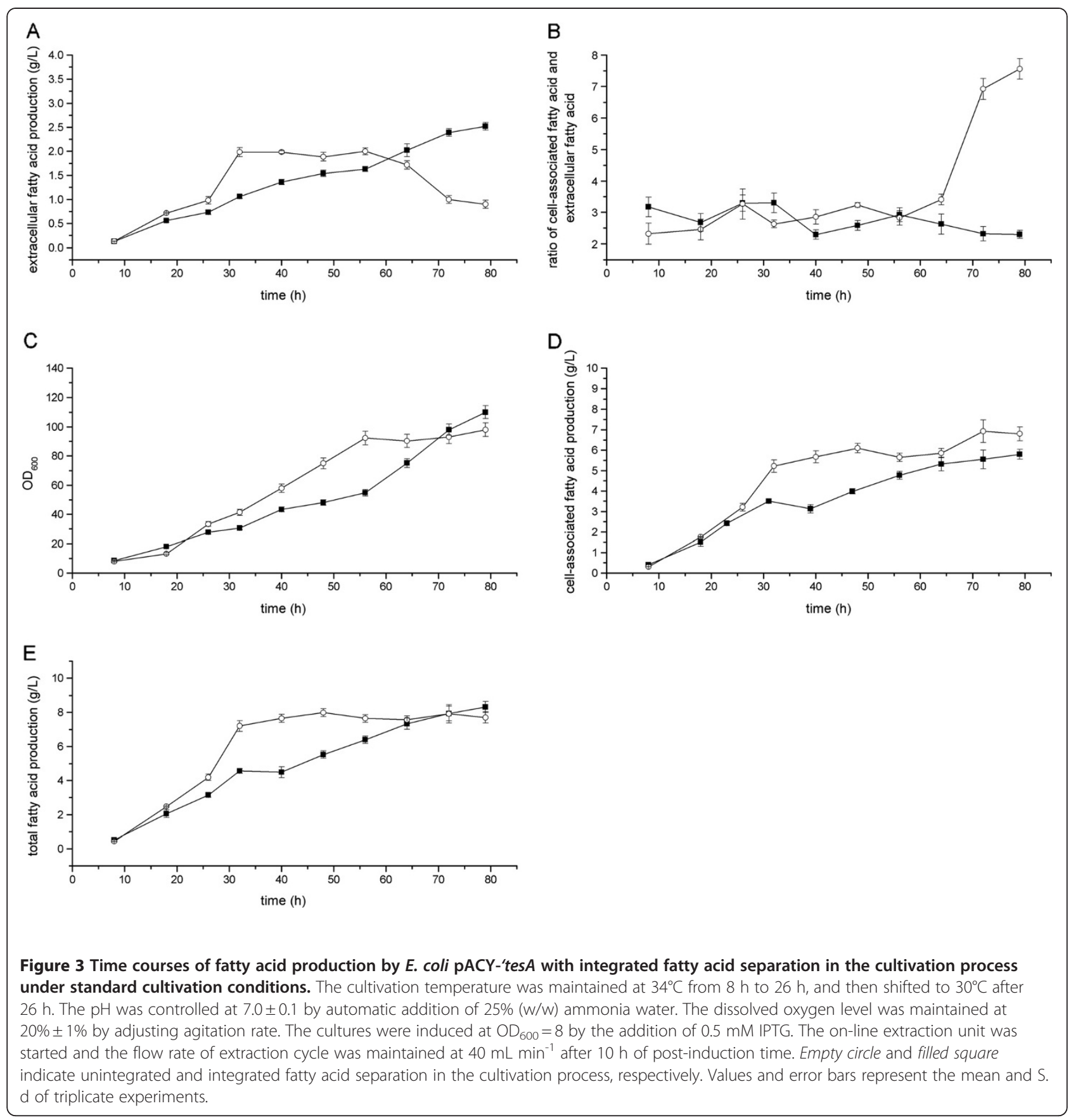

enhance the extracellular fatty acid production. This strategy has already been confirmed in genetically modified cyanobacteria[5].

Actually the chloramphenicol has to be added in the medium for plasmid stabilization in this study. However, antibiotics addition is definitely not a good option for producing low cost fatty acids for biofuel application. In order to avoid antibiotics addition in the production of biochemical products, various strategies such as addiction systems and chromosomal engineering have been implemented to construct engineering robust microbes. To avoid using the antibiotics for plasmid stabilization, addiction systems were developed by exploiting specific auxotrophic mutations and the vectors carrying the corresponding deleted genes [36,37]. The chemically inducible chromosomal evolution (CIChE) is a plasmid-free, high gene copy expression system for engineering $E$. coli, which only requires targeted genomic integration methods and a $r e c A$ homolog [38]. Therefore, the antibiotics addition could be avoided for the low cost fatty acid production with these strategies mentioned above in the future. 


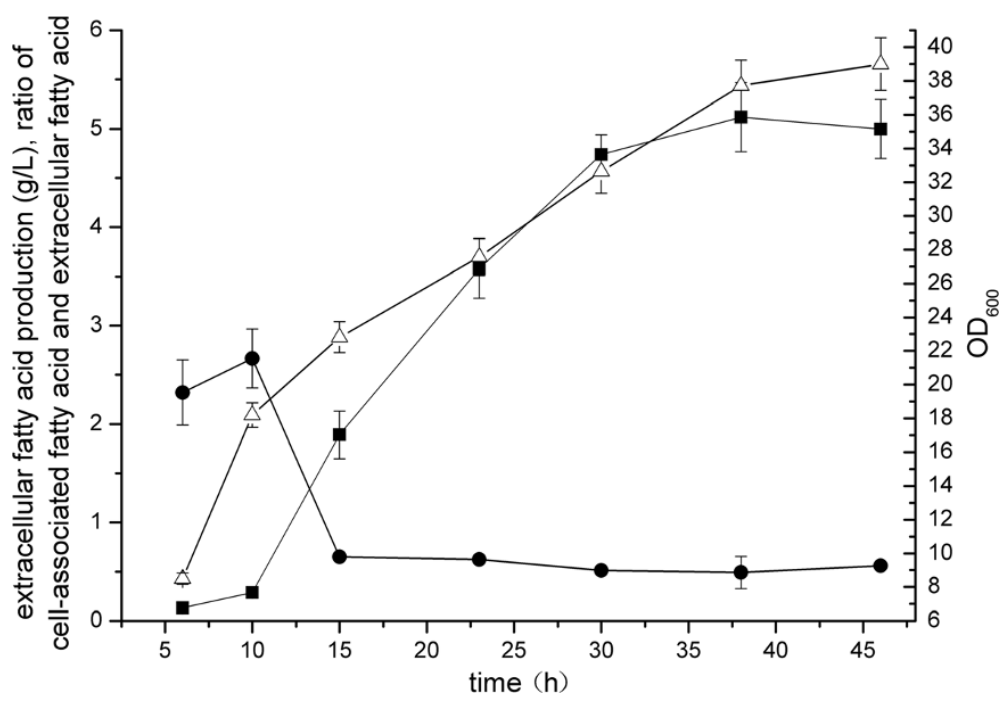

Figure 4 Time courses of fatty acid production by E. coli pACY-'tesA with addition of ampicillin in the cultivation process. Integrated fatty acid separation and standard cultivation conditions were employed. The cultivation temperature was maintained at $34^{\circ} \mathrm{C}$ from $8 \mathrm{~h}$ to $26 \mathrm{~h}$, and then shifted to $30^{\circ} \mathrm{C}$ after $26 \mathrm{~h}$. The $\mathrm{pH}$ was controlled at $7.0 \pm 0.1$ by automatic addition of $25 \%(\mathrm{w} / \mathrm{w})$ ammonia water. The dissolved oxygen level was maintained at $20 \% \pm 1 \%$ by adjusting agitation rate. The cultures were induced at $\mathrm{OD}_{600}=18$ by the addition of $0.5 \mathrm{mM}$ IPTG and $5 \mathrm{U}$ $\mathrm{mL}^{-1}$ ampicillin. The on-line extraction unit was started and the flow rate of extraction cycle was maintained at $40 \mathrm{~mL} \mathrm{~min}{ }^{-1}$ after $10 \mathrm{~h}$ of postinduction time. Filled square, filled circle, and empty upright triangle indicate extracellular fatty acid production, ratio of cell-associated fatty acid and extracellular fatty acid and $\mathrm{OD}_{600}$, respectively. Values and error bars represent the mean and S.d of triplicate experiments.

\section{Extracellular fatty acid production by $E$. coli pACY-'tesA - $\triangle$ fadL under optimal cultivation conditions}

Based on the above investigations, E. coli pACY-tesA$\triangle f a d L$ was finally employed to produce extracellular fatty acid with addition of $5 \mathrm{U} \mathrm{mL}^{-1}$ ampicillin in the cultivation process, while integrated fatty acid separation and standard cultivation conditions were employed. The time courses of fatty acid production were shown in Figure 5. The extracellular fatty acid production reached $4.8 \mathrm{~g} \mathrm{~L}^{-1}$ at $38 \mathrm{~h}$ with the volumetric productivity of $4.1 \mathrm{~g} \mathrm{~L}^{-1} \mathrm{~d}^{-1}$, the specific productivity of $0.02 \mathrm{gh}^{-1} \mathrm{~g}^{-1}$ dry cell mass, the yield of $4.4 \%$ on glucose. The ratios of cell-associated fatty acid versus extracellular fatty acid were kept below 0.5 after $15 \mathrm{~h}$ of cultivation.

Using the strain pACY-'tes $A$, similar results appeared under the same culture conditions and the titer was also much higher than that ever reported previously [5,9-11], which suggested that the supposedly superior strain did not necessarily perform best for the efficient production of desired product [19]. The strain pACY-'tesA could also be chosen as the original strain for the next genetic manipulations.

In order to rule out the possibility of increasing extracellular fatty acid due to loss of cell viability, the free fatty acid fraction of extracellular fatty acid in the supernatant was determined and approximately $90 \%$ of extracellular fatty acid was in the free form. The results suggested the loss of cell viability did exist in the cultivation process, but the improvement of extracellular fatty acid was predominately due to the secretion of free fatty acid out of cells. The increasing trend of OD also indicated that the growth rate of E. coli pACY-'tesA$\triangle f a d L$ was far beyond the inevitable loss of cell viability during the cultivation (Figure 5).

Fatty acids produced by $E$. coli pACY-'tes $A-\Delta$ fadL were analyzed by GC-MS and listed in Table 4 . The fatty acids included: C12:1, C12:0, C14:1, C14:0, C16:1, C16:0, C18:1, and C18:0. During $15 \mathrm{~h}$ to $38 \mathrm{~h}$ of cultivation, the proportions of the same length fatty acids remained relatively stable in the cell-associated fatty acid and the extracellular ones. And the composition was dominated by $\mathrm{C} 14$ and $\mathrm{C} 16$ saturated and unsaturated fatty acids.

These medium and long chain fatty acids could cause severe foaming problem during the cultivation process. The more fatty acids were produced, the more serious the foaming problem was. If the foam could not be controlled, the cultivation process would not continue normally either. In order to cope with the foaming problem, we increased the running frequency of anti-foam pump, lowered the upper surface of the foam detected by the anti-foam probe and raised the concentration of antifoam. Besides, the on-line extraction was also much helpful to solve the foaming problem through reducing the fatty acid titer in medium. Considering of the possible negative influence of reducing aeration rate on the cell metabolism for fatty acid production, the strategy of 


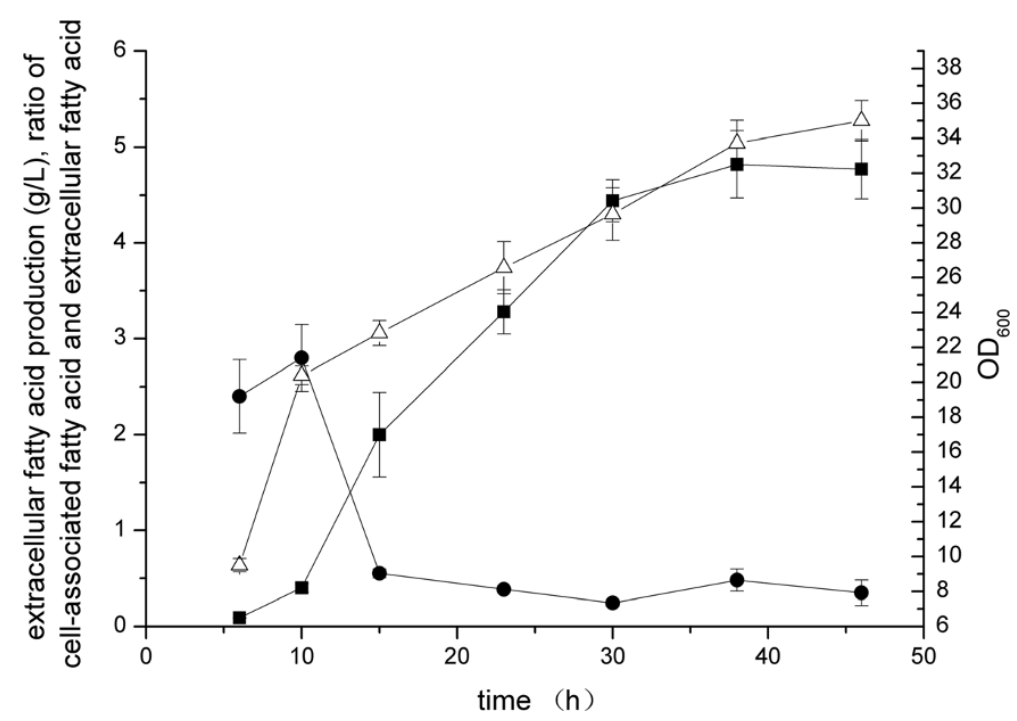

Figure 5 Time courses of fatty acid production by $E$. coli pACY-'tesA- $\triangle$ fadL with addition of ampicillin in the cultivation process. Integrated fatty acid separation and standard cultivation conditions were employed. The cultivation temperature was maintained at $34^{\circ} \mathrm{C}$ from $8 \mathrm{~h}$ to $26 \mathrm{~h}$, and then shifted to $30^{\circ} \mathrm{C}$ after $26 \mathrm{~h}$. The pH was controlled at $7.0 \pm 0.1$ by automatic addition of $25 \%(\mathrm{w} / \mathrm{w})$ ammonia water. The dissolved oxygen level was maintained at $20 \% \pm 1 \%$ by adjusting agitation rate. The cultures were induced at $\mathrm{OD}_{600}=18$ by the addition of $0.5 \mathrm{mM}$ IPTG and $5 \mathrm{U} \mathrm{mL} \mathrm{mL}^{-1}$ ampicillin. The on-line extraction unit was started and the flow rate of extraction cycle was maintained at $40 \mathrm{~mL} \mathrm{~min}{ }^{-1}$ after $10 \mathrm{~h}$ of post-induction time. Filled square, filled circle, and empty upright triangle indicate extracellular fatty acid production, ratio of cell-associated fatty acid and extracellular fatty acid and $\mathrm{OD}_{600}$, respectively. Values and error bars represent the mean and S.d of triplicate experiments.

reducing aeration rate to control foam was not employed in the cultivation process.

\section{Conclusions}

Several strategies of strain improvements and cultivation process control were successfully applied to increase extracellular fatty acid production, using ratio of cell-associated fatty acid versus extracellular fatty acid as a key parameter. The results showed 'TesA overexpression, fadL deletion, the two-stage control of cultivation temperature, ampicillin supplementation and online extraction contributed greatly to extracellular fatty acid production. Thus, the general strategy of metabolic engineering for the extracellular fatty acid production should be the cyclic optimization between cultivation performance and strain improvements. On the basis of our cultivation process optimization, strain improvements should be further carried out for the effective and cost-effective production process.

\section{Methods}

\section{Plasmid and strain construction}

The native $E$. coli thioesterase (TesA) gene and 'TesA (a 'leadless' version of TesA) gene were amplified by PCR from E. coli $\mathrm{K}-12$ (ATCC10798) genomic DNA using primers tesA-L and tesA-R, 'tesA-L and tesA-R, respectively. The

Table 4 Fatty acids produced by $E$. coli pACY-'tesA- $\Delta$ fadL with addition of ampicillin in the cultivation process

\begin{tabular}{|c|c|c|c|c|c|c|c|c|}
\hline \multirow[t]{2}{*}{ fatty acids } & \multicolumn{4}{|c|}{ Relative content of extracellular fatty acid (\%) } & \multicolumn{4}{|c|}{ Relative content of cell-associated fatty acid (\%) } \\
\hline & $15 \mathrm{~h}$ & $23 \mathrm{~h}$ & $30 \mathrm{~h}$ & $38 \mathrm{~h}$ & $15 \mathrm{~h}$ & $23 \mathrm{~h}$ & $30 \mathrm{~h}$ & $38 \mathrm{~h}$ \\
\hline C12:1 & 8.27 & 8.33 & 8.02 & 8.13 & 6.60 & 6.79 & 6.89 & 8.35 \\
\hline $\mathrm{C} 12: 0$ & 8.00 & 6.16 & 6.51 & 7.51 & 2.46 & 4.20 & 5.37 & 5.24 \\
\hline C14:1 & 14.96 & 22.79 & 21.13 & 17.84 & 24.42 & 16.96 & 18.00 & 27.67 \\
\hline C14:0 & 9.28 & 10.67 & 11.11 & 12.47 & 7.80 & 6.91 & 8.46 & 9.67 \\
\hline C16:1 & 16.33 & 8.47 & 8.26 & 7.48 & 15.47 & 29.51 & 23.04 & 10.77 \\
\hline C16:0 & 25.21 & 31.69 & 33.18 & 35.35 & 28.06 & 19.89 & 24.80 & 28.30 \\
\hline C18:1 & 7.29 & 0.86 & 2.28 & 2.52 & 2.36 & 8.22 & 5.68 & 2.28 \\
\hline C18:0 & 10.68 & 11.03 & 9.50 & 7.72 & 12.83 & 7.51 & 7.76 & 7.72 \\
\hline
\end{tabular}

Integrated fatty acid separation and standard cultivation conditions were employed. 
amplified TesA gene was inserted into pACYCDuet-1 (Novagen) between the $\mathrm{NcoI}$ and BamHIsites to generate pACY-tesA. The amplified 'TesA gene was inserted into pACYCDuet-1 (Novagen) between the EcoRI and SalI sites to generate pACY-'tesA. E. coli BL21 (DE3) (Invitrogen) was used as a host for the expression of the TesA and 'TesA genes. The primers used above were listed in Table 5. Bacterial strains and plasmids used in this study were listed in Table 6.

According to the protocol of the TargeTron Gene Knockout System Kit (Sigma-Aldrich), the retargeted intron DNA fragments $f a d D$-intron and $f a d L$-intron were amplified by overlap PCR using primer set 1 (fadD-IBS, fadD-EBS1d, fadD-EBS2 and EBS universal primer) and primer set 2 (fadL-IBS, fadL-EBS1d, fadL-EBS2 and EBS universal primer), respectively. These primers listed in Table 5 were designed using the TargeTron prediction program (www.Sigma-Aldrich.com/ Targetronaccess). The two resultant DNA fragments were cloned into the HindIII and BsrGI restriction sites of pACD4K-C for the deletion of $f a d D$ and $f a d L$ in E. coli BL21 (DE3) (Invitrogen). The resultant strains were used as hosts for the expression of the 'TesA gene.

\section{Cultivation conditions in shake flasks}

A single colony of $E$. coli pACY-'tes $A$ or pACY-tes $A$ was inoculated to $5 \mathrm{~mL}$ M9 minimal medium $\left(15.12 \mathrm{gL}^{-1}\right.$ $\mathrm{Na}_{2} \mathrm{HPO}_{4} \cdot 12 \mathrm{H}_{2} \mathrm{O}, 3 \mathrm{~g} \mathrm{~L}^{-1} \mathrm{KH}_{2} \mathrm{PO}_{4}, 1 \mathrm{~g} \mathrm{~L}^{-1} \mathrm{NH}_{4} \mathrm{Cl}, 0.5 \mathrm{~g} \mathrm{~L}^{-1}$ $\mathrm{NaCl}$ ) supplemented with $34 \mu \mathrm{g} \mathrm{mL} \mathrm{m}^{-1}$ chloramphenicol and cultured overnight at $37^{\circ} \mathrm{C}[39]$. Three percent (v/v) inocula was added aseptically to a $500-\mathrm{mL}$ shake flask containing $50 \mathrm{~mL}$ M9 minimal medium supplemented with glucose $\left(20 \mathrm{gL}^{-1}\right)$ as primary carbon source and $34 \mu \mathrm{g} \mathrm{mL} \mathrm{L}^{-1}$ chloramphenicol, and was cultivated at $37^{\circ} \mathrm{C}$ and $180 \mathrm{rpm}$. The cultures were induced at an optical density $\left(\mathrm{OD}_{600}\right)$ of 0.6 by the addition of $0.5 \mathrm{mM}$ isopropylthiogalactoside (IPTG) at $30^{\circ} \mathrm{C}$ and samples were collected $20 \mathrm{~h}$ post-induction for fatty acids analysis. To evaluate the effects of ampicillin on the biomass and fatty acids secretion, various concentrations of ampicillin were added in culture broth at $\mathrm{OD}_{600}=1.4$.

\section{Fed-batch cultivation}

A single colony of $E$. coli pACY-'tes $A$, pACY-'tes $A-\triangle$ fadD or pACY-'tesA- $\triangle f a d L$ was inoculated to a $500-\mathrm{mL}$ shake flask containing $25 \mathrm{~mL}$ M9 minimal medium supplemented with glucose $\left(20 \mathrm{gL}^{-1}\right)$ as primary carbon source and $34 \mu \mathrm{g} \mathrm{mL}{ }^{-1}$ chloramphenicol, and was cultivated at $37^{\circ} \mathrm{C}$, $180 \mathrm{rpm}$ for $12 \mathrm{~h}$. Three percent (v/v) inocula was added aseptically to 5 -L jar fermentors (BIOSTAT Bplus 5 L, Sartorius stedim) containing $3 \mathrm{~L}$ medium consisted of the following components: $3 \mathrm{~g}\left(\mathrm{NH}_{4}\right)_{2} \mathrm{SO}_{4}, 9 \mathrm{~g} \mathrm{~K} \mathrm{HPO}_{4} \cdot 3 \mathrm{H}_{2} \mathrm{O}$, $9.45 \mathrm{~g} \mathrm{MgSO}_{4} \cdot 7 \mathrm{H}_{2} \mathrm{O}, 5.7 \mathrm{~g} \mathrm{KCl}, 3 \mathrm{~g}$ sodium citrate, 3 g citric acid, $60 \mathrm{~g}$ glucose, $15 \mathrm{~mL}$ corn steep liquid (corresponding to $0.47 \mathrm{~g}$ of nitrogen) and $3 \mathrm{~mL}$ trace elements $(0.37 \mathrm{~g}$ $\left(\mathrm{NH}_{4}\right)_{6} \mathrm{Mo}_{7} \mathrm{O}_{24} \cdot 4 \mathrm{H}_{2} \mathrm{O}, 0.29 \mathrm{~g} \mathrm{ZnSO}_{4} \cdot 7 \mathrm{H}_{2} \mathrm{O}, 2.47 \mathrm{~g} \mathrm{H}_{3} \mathrm{BO}_{3}$, $\left.0.25 \mathrm{~g} \mathrm{CuSO}_{4} \cdot 5 \mathrm{H}_{2} \mathrm{O}, 1.58 \mathrm{~g} \mathrm{MnCl}_{2} \cdot 4 \mathrm{H}_{2} \mathrm{O}\right)$. The cultivation temperature was maintained at $34^{\circ} \mathrm{C}$ from $8 \mathrm{~h}$ to $26 \mathrm{~h}$, and then shifted to $30^{\circ} \mathrm{C}$ from $26 \mathrm{~h}$ to $72 \mathrm{~h}$ unless specified according to different purposes. The $\mathrm{pH}$ was controlled at $7.0 \pm 0.1$ by automatic addition of $25 \%(\mathrm{w} / \mathrm{w})$ ammonia water. The aeration rate was $3 \mathrm{vvm}$ and dissolved oxygen level was maintained at $20 \% \pm 1 \%$ by adjusting agitation rate. When the initial glucose was depleted, $800 \mathrm{gL}^{-1}$ concentrated glucose was intermittently fed into the fermentor at a constant flow rate of $4.2 \mathrm{~g} \mathrm{~L}^{-1} \mathrm{~h}^{-1}$. The cultures were induced at $\mathrm{OD}_{600}=8$ by the addition of $0.5 \mathrm{mM}$ IPTG and samples were collected at certain intervals for fatty acids analysis.

\section{Integration of fatty acids separation with fed-batch cultivation}

The 5-L jar fermentor (BIOSTAT Bplus 5 L, Sartorius stedim) was combined with an extraction unit using a 500-mL glass jar containing $200 \mathrm{~mL}$ tributyl phosphate

Table 5 Primers used in the study

\begin{tabular}{|c|c|}
\hline Primer name & Sequence $\left(5^{\prime}-3^{\prime}\right)$ \\
\hline tesA-L & CATGCCATGGTTATGATGAAC TTCAACAATGTITCC \\
\hline tesA-R & CGCGGATCCTITATGAGTCA TGATITACTAAAGGC \\
\hline 'tesA-L & CGGAATTCGGCGGACACGTTA TTGATTCTGGG \\
\hline 'tesA-R & ACGCGTCGACTTATGAGTCATGAT TTACTAAAGGC \\
\hline fadD-IBS & AAAAAAGCTTATAATTATCCTTAGGATTCCTGCGCGTGCGCCCAGATAGGGTG \\
\hline fadD-EBS1d & CAGATTGTACAAATGTGGTGATAACAGATAAGTCCTGCGCATTAACTTACCTITCITGT \\
\hline EBS2-fadD & TGAACGCAAGTITCTAATITCGATTAATCCTCGATAGAGGAAAGTGTCT \\
\hline fadL-IBS & AAAAAAGCTTATAATTATCCTTAGGTTACAACCTGGTGCGCCCAGATAGGGTG \\
\hline fadL-EBS1d & CAGATTGTACAAATGTGGTGATAACAGATAAGTCAACCTGACTAACTIACCTITCTITGT \\
\hline fadL-EBS2 & TGAACGCAAGTITCTAATTTCGATTTAACCTCGATAGAGGAAAGTGTCT \\
\hline EBS universal & CGAAATTAGAAACTTGCGTTCAGTAAAC \\
\hline
\end{tabular}


Table 6 Bacterial strains and plasmids used in this study

\begin{tabular}{|c|c|c|}
\hline Strain / plasmid & Relevant genotype / property & Source / reference \\
\hline \multicolumn{3}{|l|}{ Strains } \\
\hline E. coli BL21(DE3) & $\mathrm{F}^{-}$ompT hsdS $\left(r_{B}^{-} m_{B}^{-}\right)$gal dcm rne131(DE3) & Invitrogen \\
\hline E. coli K-12 & Type strain & ATCC \\
\hline E. coli pACY-tesA & BL21(DE3) / pACY-tesA & This study \\
\hline E. coli pACY-'tesA & BL21(DE3) / pACY-'tesA & This study \\
\hline E. coli pACY-'tesA- $\triangle$ fadD & BL21(DE3) $\Delta$ fadD / pACY-'tesA & This study \\
\hline E. coli pACY-'tesA- $\Delta$ fadL & BL21(DE3) $\Delta$ fadL / pACY-'tesA & This study \\
\hline E. coli pACYCDuet-1 & BL21 (DE3) /pACYCDuet-1 & This study \\
\hline \multicolumn{3}{|l|}{ Plasmids } \\
\hline pACYCDuet-1 & P15A origin, lacla, $\mathrm{T} 7$ promoter, $\mathrm{Cm}^{\mathrm{R}}$ & Novagen \\
\hline pACY-tesA & pACYCDuet-1 derivative carrying tes $A$ gene, $T 7$ promoter, $\mathrm{Cm}^{\mathrm{R}}$ & This study \\
\hline pACY-'tesA & pACYCDuet-1 derivative carrying 'tesA gene (without leading sequence), $T 7$ promoter, $\mathrm{Cm}^{\mathrm{R}}$ & This study \\
\hline
\end{tabular}

(TBP) (Figure 6). The integrated fatty acids separation system in the fed-batch cultivation employed a flow cycle between the 5-L jar fermentor and the 500-mL extraction jar. The cultivation broth was pumped from the fermentor to the glass jar and pumped back into the fermentor after the extraction operation. The culture conditions were the same as the fed-batch cultivation. The on-line extraction unit was started and the flow rate of extraction cycle was maintained at $40 \mathrm{~mL} \mathrm{~min}{ }^{-1}$ after $10 \mathrm{~h}$ of post-induction time. To evaluate the effects of ampicillin supplementation on the fatty acid production and secretion, the cultures

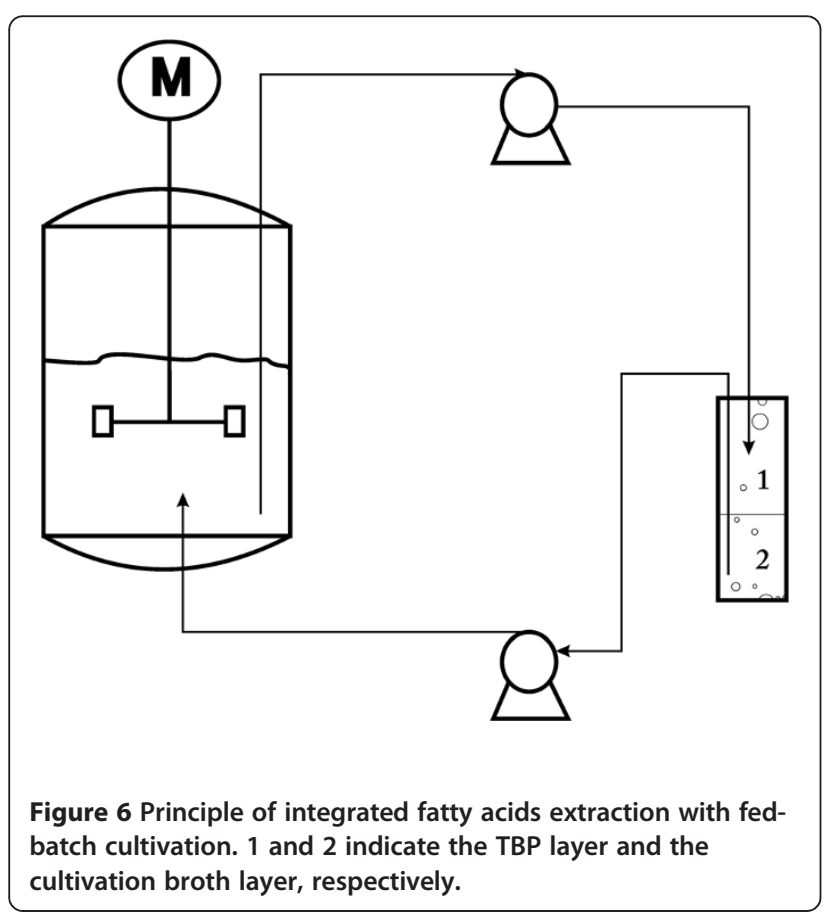

were induced at $\mathrm{OD}_{600}=18$ by the addition of $0.5 \mathrm{mM}$ IPTG and $5 \mathrm{U} \mathrm{mL}^{-1}$ ampicillin.

Fatty acid extraction, saponification and methylation 5-mL samples of cell culture (three replicates for each sample) were centrifuged at $8000 \mathrm{rpm}$ for $10 \mathrm{~min}$ to separate the cell-associated fatty acid and extracellular fatty acid. The extracellular fatty acid in the supernatants was extracted three times with $20 \mathrm{~mL}$ of chloroform/ methanol mixture $(2: 1, \mathrm{v} / \mathrm{v})$. The cell pellets were resuspended in $1 \mathrm{~mL}$ distilled water and mixed with $20 \mathrm{~mL}$ chloroform/ methanol mixture $(2: 1, \mathrm{v} / \mathrm{v})$ to obtain cellassociated fatty acid as previously described [9]. $100 \mu \mathrm{L}$ of $10 \mathrm{gL}^{-1}$ arachidic acid (Alfa Aesar) was added as the internal standard respectively. The chloroform layer was evaporated under a nitrogen stream and the dried fatty acid sample was used for the analysis of extracellular, cellassociated or free fatty acid.

For the extracellular or cell-associated fatty acid analysis, the dried fatty acid was redissolved in $2 \mathrm{~mL}$ of $20 \mathrm{gL}^{-1}(\mathrm{w} / \mathrm{v}) \mathrm{NaOH}$ in methanol/ water mixture (4:1, $\mathrm{v} / \mathrm{v})$ and the saponification reaction was incubated at $60^{\circ}$ $\mathrm{C}$ for one hour. To methylate the fatty acids, $3 \mathrm{~mL}$ of $\mathrm{BF}_{3} / \mathrm{CH}_{3} \mathrm{OH}(1: 4, \mathrm{v} / \mathrm{v})$ and $170 \mu \mathrm{L}$ of $6 \mathrm{~mol} \mathrm{~L}^{-1} \mathrm{HCl}$ were added and the reaction was incubated at $60^{\circ} \mathrm{C}$ for $30 \mathrm{~min}$. The fatty acid methyl esters (FAMEs) were extracted twice using $1.5 \mathrm{~mL}$ of $\mathrm{n}$-hexane and collected for analysis.

For the free fatty acid analysis, the dried fatty acid was redissolved in $500 \mu \mathrm{L}$ of chloroform/ methanol mixture $(2: 1, \mathrm{v} / \mathrm{v})$ and loaded on the thin-layer chromatography (TLC) plate. The TLC plate was developed with hexanediethyl-ether-formic acid (70:30:0.2, v/v/v) [40]. The free fatty acid was identified and eluted out with chloroform and dried. To methylate the fatty acids, $3 \mathrm{~mL}$ of $\mathrm{BF}_{3} /$ 
$\mathrm{CH}_{3} \mathrm{OH}(1: 4, \mathrm{v} / \mathrm{v})$ and $170 \mu \mathrm{L}$ of $6 \mathrm{~mol} \mathrm{~L}^{-1} \mathrm{HCl}$ were added and the reaction was incubated at $60^{\circ} \mathrm{C}$ for $30 \mathrm{~min}$. The fatty acid methyl esters (FAMEs) were extracted twice using $1.5 \mathrm{~mL}$ of $\mathrm{n}$-hexane and collected for analysis.

\section{Gas chromatography/ mass spectrometry and gas chromatography of fatty acid methyl esters}

Gas chromatography/ mass spectrometry (GC/MS) analysis was performed in a Thermo Fisher Trace GC UltraITQ1100 system with a 30-m HP-5 ms column. The column temperature program was $100^{\circ} \mathrm{C}$ for $2 \mathrm{~min}$, a ramp to $280^{\circ} \mathrm{C}$ at a rate of $10^{\circ} \mathrm{C} \mathrm{m^{-1 }}$ and $280^{\circ} \mathrm{C}$ for $3 \mathrm{~min}$.

The gas chromatography (GC) analysis of FAMEs was performed in a Varian GC-450 system equipped with a 30-m HP-5 column and using nitrogen as carrier gas with a linear velocity of $1 \mathrm{~mL} \mathrm{~min}^{-1}$. GC elution conditions were as follows: $100^{\circ} \mathrm{C}$ for $2 \mathrm{~min}$, a ramp to $250^{\circ} \mathrm{C}$ at a rate of $10^{\circ} \mathrm{C} \mathrm{min}^{-1}$ and a final hold at $250^{\circ} \mathrm{C}$ for 5 min. The split ratio was $1: 10$ or $1: 50$. The quantification of fatty acids was achieved with reference to the internal standard (arachidic acid) and the response factors and averaged for all replicates.

\section{Calculations}

The following equation was used to calculate the specific productivity [41].

$$
Q_{p}=\frac{p_{1}-p_{0}}{t_{1}-t_{0}} \times \frac{2}{x_{1}+x_{0}}
$$

Where $\mathrm{Q}_{\mathrm{p}}$, Specific production rate $\left(\mathrm{g} \mathrm{h}^{-1} \mathrm{~g}^{-1}\right.$ dry cell); $\mathrm{p}$, Fatty acid concentration $(\mathrm{g} / \mathrm{L})$; t, Cultivation time (h); $\mathrm{x}$, biomass $(\mathrm{g} / \mathrm{L})$.

Cell culture optical density was measured at $600 \mathrm{~nm}$ using a spectrophotometer ( Cary 50 UV-vis, VARIAN) and the dry cell weight was calculated according to the coefficient (one $\mathrm{OD}_{600}$ unit corresponded to $0.43 \mathrm{~g} \mathrm{~L}^{-1}$ of dry cell weight).

Competing interests

The authors declare that they have no competing interests.

\section{Acknowledgements}

This work was supported by the Natural Science Foundation of Shandong Province (Y2008B43) and the National Natural Science Foundation (21106170).

\footnotetext{
Authors' contributions

$\mathrm{HL}$ and $\mathrm{CY}$ conceived of the study, participated in its design, carried out the process control studies and drafted the manuscript. DF participated in the coordination of this study, contributed to the GC-MS data analysis and helped to draft the manuscript. TC carried out the molecular genetic studies and the process control studies. XM carried out the molecular genetic studies. WL and $\mathrm{HZ}$ helped to draft the manuscript. MX conceived of the study, and participated in its design and coordination and helped to draft the manuscript. All authors read and approved the final manuscript.
}

Received: 16 February 2012 Accepted: 3 April 2012

Published: 3 April 2012

\section{References}

1. Li Q, Du W, Liu D: Perspectives of microbial oils for biodiesel production Appl Microbiol Biotechnol 2008, 80(5):749-756.

2. Xu P, Koffas MAG: Metabolic engineering of Escherichia coli for biofuel production. Biofuels, 2010 1(3):493-504.

3. DOE: National Algal Fuels Technology Roadmap. (http://wwworau.gov/ algae2008/resources.htm). 2008

4. Molina Grima E, Belarbi EH, Acien Fernandez FG, Robles Medina A, Chisti Y: Recovery of microalgal biomass and metabolites: process options and economics. Biotechnol Adv 2003, 20(7-8):491-515.

5. Liu X, Sheng J, Curtiss lii R: Fatty acid production in genetically modified cyanobacteria. Proc Natl Acad Sci 2011, 108(17):6899-6904.

6. Stahl A, Gimeno RE, Tartaglia LA, Lodish HF: Fatty acid transport proteins: a current view of a growing family. Trends Endocrinol Metab 2001, 12(6):266-273.

7. Nunn WD, Colburn RW, Black PN: Transport of long-chain fatty acids in Escherichia coli. Evidence for role of fadL gene product as long-chain fatty acid receptor. J Biol Chem 1986, 261(1):167-171.

8. Wang X, Karbarz MJ, McGrath SC, Cotter RJ, Raetz CRH: MsbA Transporterdependent Lipid A 1-Dephosphorylation on the Periplasmic Surface of the Inner Membrane. J Biol Chem 2004, 279(47):49470-49478.

9. Voelker TA, Davies HM: Alteration of the specificity and regulation of fatty acid synthesis of Escherichia coli by expression of a plant medium-chain acyl-acyl carrier protein thioesterase. J Bacteriol 1994, 176(23):7320-7327.

10. Scharnewski M, Pongdontri P, Mora G, Hoppert M, Fulda M: Mutants of Saccharomyces cerevisiae deficient in acyl-CoA synthetases secrete fatty acids due to interrupted fatty acid recycling. FEBS J 2008, 275(11):27652778.

11. Lu X, Vora H, Khosla C: Overproduction of free fatty acids in E. coli: Implications for biodiesel production. Metab Eng 2008, 10(6):333-339.

12. Steen EJ, Kang Y, Bokinsky G, Hu Z, Schirmer A, McClure A, del Cardayre SB, Keasling JD: Microbial production of fatty-acid-derived fuels and chemicals from plant biomass. Nature 2010, 463(7280):559-562.

13. Davis MS, Solbiati J, Cronan JE: Overproduction of Acetyl-CoA Carboxylase Activity Increases the Rate of Fatty Acid Biosynthesis in Escherichia coli. J Biol Chem 2000, 275(37):28593-28598.

14. Li SJ, Cronan JE Jr: Growth rate regulation of Escherichia coli acetyl coenzyme A carboxylase, which catalyzes the first committed step of lipid biosynthesis. J Bacteriol 1993, 175(2):332-340.

15. Jiang P, Cronan JE Jr: Inhibition of fatty acid synthesis in Escherichia coli in the absence of phospholipid synthesis and release of inhibition by thioesterase action. J Bacteriol 1994, 176(10):2814-2821.

16. Cho H, Cronan JE: Defective Export of a Periplasmic Enzyme Disrupts Regulation of Fatty Acid Synthesis. J Biol Chem 1995, 270(9):4216-4219.

17. Liu T, Vora H, Khosla C: Quantitative analysis and engineering of fatty acid biosynthesis in E. coli. Metab Eng 2010, 12(4):378-386.

18. Liao JC, Hou SY, Chao YP: Pathway analysis, engineering, and physiological considerations for redirecting central metabolism. Biotechnol Bioeng 1996, 52(1):129-140.

19. Lee SY, Kim HU, Park JH, Park JM, Kim TY: Metabolic engineering of microorganisms: general strategies and drug production. Drug Discov Today 2009, 14(1-2):78-88.

20. Stephanopoulos G: Challenges in Engineering Microbes for Biofuels Production. Science 2007, 315(5813):801-804.

21. Lennen RM, Braden DJ, West RM, Dumesic JA, Pfleger BF: A process for microbial hydrocarbon synthesis: Overproduction of fatty acids in Escherichia coli and catalytic conversion to alkanes. Biotechnol Bioeng 2010, 106(2):193-202.

22. Natalia Sanchez de G, Salvador V: Effect of temperature on protein quality in bacterial inclusion bodies. FEBS Lett 2006, 580(27):6471-6476.

23. Hunke S, Betton JM: Temperature effect on inclusion body formation and stress response in the periplasm of Escherichia coli. Mol Microbiol 2003, 50(5):1579-1589.

24. Feng Y, Cronan JE: Escherichia coli Unsaturated Fatty Acid Synthesis. J Bio Chem 2009, 284(43):29526-29535.

25. Jones KL, Kim S-W, Keasling JD: Low-Copy Plasmids can Perform as Well as or Better Than High-Copy Plasmids for Metabolic Engineering of Bacteria. Metab Eng 2000, 2(4):328-338.

26. Cho $\mathrm{H}$, Cronan JE: Escherichia coli thioesterase I, molecular cloning and sequencing of the structural gene and identification as a periplasmic enzyme. J Biol Chem 1993, 268(13):9238-9245. 
27. Jochen B: Introduction to advantages and problems of shaken cultures. Biochem Eng J 2001, 7(2):91-98.

28. Schein CH: Production of Soluble Recombinant Proteins in Bacteria. Nat Biotechnol 1989, 7(11):1141-1149.

29. Black PN, DiRusso CC: Transmembrane Movement of Exogenous LongChain Fatty Acids: Proteins, Enzymes, and Vectorial Esterification. Microbiol Mol Biol Rev 2003, 67(3):454-472.

30. Maass D, Gerigk MR, Kreutzer A, Weuster-Boltz D, Wubbolts M, Takors R: Integrated L-phenylalanine separation in an E. coli fed-batch process: from laboratory to pilot scale. Bioprocess Biosyst Eng 2002, 25(2):85-96. Schugerl K: Integrated processing of biotechnology products. Biotechnol Adv 2000, 18(7):581-599.

32. Schugerl K, Hubbuch J: Integrated bioprocesses. Curr Opin Microbiol 2005, 8 (3):294-300.

33. HKumagai2000Microbial Production of Amino Acids in JapanAFiechterHistory of Modern Biotechnology Ivol. 69Springer BerlinHeidelberg7185Kumagai $\mathrm{H}$ : Microbial Production of Amino Acids in Japan. In History of Modern Biotechnology I. vol. 69th edition. Edited by Fiechter A. Heidelberg: Springer Berlin; 2000:71-85.

34. Jean-Marie G: Penicillin-binding proteins. Wall peptidoglycan assembly and resistance to penicillin: facts, doubts and hopes. Int J Antimicrob Agents 1997, 8(1):45-60.

35. Den Blaauwen T, Aarsman MEG, Vischer NOE, Nanninga N: Penicillinbinding protein PBP2 of Escherichia coli localizes preferentially in the lateral wall and at mid-cell in comparison with the old cell pole. Mol Microbiol 2003, 47(2):539-547.

36. Hagg P, de Pohl JW, Abdulkarim F, Isaksson LA: A host/plasmid system that is not dependent on antibiotics and antibiotic resistance genes for stable plasmid maintenance in Escherichia coli. J Biotechnol 2004, 111 (1):17-30.

37. Kroll J, Steinle A, Reichelt R, Ewering C, Steinbuchel A: Establishment of a novel anabolism-based addiction system with an artificially introduced mevalonate pathway: Complete stabilization of plasmids as universal application in white biotechnology. Metab Eng 2009, 11(3):168-177.

38. Tyo KEJ, Ajikumar PK, Stephanopoulos G: Stabilized gene duplication enables long-term selection-free heterologous pathway expression. Nat Biotech 2009, 27(8):760-765.

39. Yun M, Park C-G, Kim J-Y, Rock CO, Jackowski S, Park H-W: Structural Basis for the Feedback Regulation of Escherichia coli Pantothenate Kinase by Coenzyme A. J Biol Chem 2000, 275(36):28093-28099.

40. Striby L, Lafont R, Goutx M: Improvement in the latroscan thin-layer chromatographic-flame ionisation detection analysis of marine lipids. Separation and quantitation of monoacylglycerols and diacylglycerols in standards and natural samples. Journal of Chromatography A 1999, 849 (2):371-380

41. Tashiro Y, Takeda K, Kobayashi G, Sonomoto K, Ishizaki A, Yoshino S: High butanol production by Clostridium saccharoperbutylacetonicum N1-4 in fed-batch culture with $\mathrm{pH}$-Stat continuous butyric acid and glucose feeding method. J Biosci Bioeng 2004, 98(4):263-268.

doi:10.1186/1475-2859-11-41

Cite this article as: Liu et al: Production of extracellular fatty acid using engineered Escherichia coli. Microbial Cell Factories 2012 11:41.

\section{Submit your next manuscript to BioMed Central and take full advantage of:}

- Convenient online submission

- Thorough peer review

- No space constraints or color figure charges

- Immediate publication on acceptance

- Inclusion in PubMed, CAS, Scopus and Google Scholar

- Research which is freely available for redistribution

Submit your manuscript at www.biomedcentral.com/submit 